\title{
The World Trade Organization's legitimacy crisis
}

\author{
DANIEL C. ESTY* \\ Yale Law School, Yale School of Forestry and Environmental Studies
}

\begin{abstract}
Despite the successful launch of a new round of multilateral trade negotiations at Doha, the World Trade Organization faces a legitimacy crisis. Protests continue to rock major international economic meetings, and the WTO's role in globalization is being questioned by many observers. This paper examines the contours of this crisis and explores the possibility that the WTO's indirect ties to popular sovereignty - through national governments - provide an insufficient foundation for the trade regime's authority and central role in the emerging structure of global governance. Arguing that the WTO needs to re-establish its legitimacy based on wider links to the public around the world in whose name freer trade is pursued, the paper suggests that the WTO must also re-build its reputation for efficacy in a context where success is no longer measured exclusively in narrow economic terms. To be seen as serving the interests of the world community broadly, the trade regime needs to pursue its economic goals in a fashion that shows sensitivity to other important goals and values, such as poverty alleviation, environmental protection, and the promotion of public health. Long-term success further depends on the trade regime becoming embedded within a broader structure of global governance that provides 'checks and balances' and reinforces the legitimacy of international trade policy making.
\end{abstract}

Turmoil surrounds the international trading system and especially the World Trade Organization (WTO). The 1999 WTO Ministerial Meeting in Seattle broke down in chaos. Other international gatherings to promote economic integration, including the European Union's 2000 Summit Meeting in Gothenburg and the 2001 Summit of the Americas in Quebec City, have triggered similar protests and violent clashes between demonstrators and the police. Undoubtedly, the anti-globalization backlash and the rioting in the streets has a number of causes (Blackhurst, 2001; Esty, 2000). And, while some commentators have dismissed the demonstrations as mere 'noise', I believe a 'signal' can be extracted from the current difficulties of the trade regime. Simply put, the international trading system has not adapted to a rapidly changing global scene - and now faces a serious legitimacy crisis (Keohane and Nye, 2001). This article explores the origins and implications of this crisis.

I argue that the WTO stands at a watershed. The post-World War II international

* Correspondence: Yale Center for Environmental Law \& Policy, 205 Prospect Street, New Haven, CT 06511 USA. Email: 〈daniel.esty@yale.edu〉. 
order centered on issue-based 'decomposable hierarchies' has begun to break down (Simon, 1996; Keohane and Nye, 2001). ${ }^{1}$ A new, more complex and fluid international system is beginning to emerge. But the new architecture has structural flaws. In particular, little attention has been paid to what is required to establish the legitimacy of international organizations in general and the WTO in particular (Bodansky, 1999; Hurd, 1999; Stephan, 1999).

The WTO appears simultaneously to be at the leading edge of the economic integration process and yet curiously old-fashioned and out of step with some modern norms, particularly those involving good public decisionmaking. As recent events have demonstrated, coherently managing interdependence is of vital importance. This need makes the resolution of the legitimacy issues surrounding the WTO of even greater urgency.

Many of those who criticize the WTO and other elements of international economic structure have little foundation for the charges they make. Indeed, many of the attacks on the WTO are off-base and deeply confused. The suggestion, for instance, that freer trade leads to greater poverty disregards the enormous gains that have been made by hundreds of millions of people across the planet over the last several decades in countries that have opened themselves up to world markets (Bhagwati, 1993; Anderson and Blackhurst, 1992). Those chanting 'no WTO' really do not want an international marketplace without structure or rules in which multinational corporations operate without constraints.

\section{Legitimate concerns}

While much of the criticism of the WTO is analytically unfounded and some of it is positively up side down and backwards, there are a number of kernels of truth in the general angst about the future that is manifested in anti-globalization rhetoric. First, trade liberalization creates losers as well as winners. There can be no doubt, furthermore, that we live in a time of considerable turbulence. Fears about job insecurity and the prospect of wages being bid down in the globalized labor market have some foundation, even if the long-term broader economic trend is positive for most people.

Second, economic integration and the broader forces of globalization threaten some traditions and local cultures. But these changes - for example, the evolving rhythms of rural life in France, which Jose Bové decries - are not the product of some grand conspiracy but rather choices by everyday people about how they want to lead their lives (Jeffress and Mayanobe, 2001). Similarly, the urbanization of countries

1 As Keohane and Nye explain, we are shifting from a mode of international relations in which people interact only through governments and where tightly controlled inter-governmental regimes facilitate international cooperation with regard to particular issue areas. This system can be seen as 'decomposable' to the extent that the specific regimes operate quite independently, with rules and traditions developed by a tightknit 'community' (that is, national government officials and a small number of officials serving as the staff to the relevant international organization) in the issue-area, making it hard for 'outsiders' (NGOs, new state actors, media, etc.) to participate. 
The World Trade Organization's legitimacy crisis 9

across the world, the commercial prominence of global brands and multinational corporations, and the powerful presence of a worldwide media and entertainment culture are driven largely by public preferences. But the fear that an overemphasis on materialism and economic growth will result in policies that run roughshod over other values about which people care has an underlying logic. It may, for example, be more difficult to follow through on concerns about the environment or human rights within the context of an economic dynamic of global competition (Esty, 1996; Esty and Geradin, 2001).

Third, the benefits of trade liberalization and economic integration may not be fairly distributed. In many countries the general public benefits from access to a greater variety of goods at lower prices (Gilpin, 1987). But in some nations, elite groups dominate both political processes and the economy, allowing them to claim a vastly disproportionate share of the 'spoils' of freer trade and economic growth more generally (O'Rourke, 2001). Thus, distributional questions cannot be ignored.

Too often the trade community leaders duck these concerns, arguing that economic transactions always result in some dislocation, that environmental harms are not related to trade, and that equity issues should be dealt with in other fora . But to disregard these issues damages the credibility of those pressing the trade liberalization agenda - and may mean that economic integration proceeds in ways that do not maximize social welfare (Esty, 2001).

\section{The underlying legitimacy crisis}

Beyond these broad sources of concern about trade liberalization lie a set of questions about the WTO specifically. In fact, the WTO's very legitimacy has been called into question (Weinstein and Charnovitz, 2001; Stokes and Choate, 2001; Bodansky, 1999). Public acceptance of the authority and decisions that emerge from the World Trade Organization can no longer be taken for granted in many countries.

Legitimacy is a complex concept in the context of governance. It can be derived through elections and a majority vote for representatives who reflect the political will of a community (in the spirit of Rousseau) (Franck, 1990). Alternatively, a governing body may gain authority and public acceptance based on reason and the efficacy of the outcomes it generates (in the Kantian tradition) (Kahn, 1989). Popular sovereignty and efficacy are to some extent fungible. Thus, some governments maintain their hold on power because they continue to win elections even though their results in office are not outstanding (consider the regimes in Argentina over the past century). In other cases, governments fall short of full democratic practices (think of Singapore), but maintain public support and acceptance by their effectiveness and their capacity to deliver on public expectations. As a general rule, people appear more willing to cede authority to 'expert' decisionmaking in realms that are perceived to be technical or scientific (Kahn, 1989; Weber, 2000). The American public, for example, has seemed quite willing to leave monetary policy in 
the hands of the not-too-democratic Federal Reserve Board under the leadership of Alan Greenspan so long as the economy remained strong. ${ }^{2}$

Legitimacy also has a systemic dimension. The authority of a particular decisionmaking body depends not only on the electoral accountability of those making decisions or the perceived rationality of the choices that emerge but also on the popular sovereignty and efficacy of the broader system within which a decisionmaking entity is lodged (Breton, 1996; Hurd, 1999). Thus, for example, the US Supreme Court has a high degree of legitimacy although its justices are not elected and its decisions sometimes appear to fall short of full rationality. But the US Supreme Court is embedded in a broader structure of legislative, executive, and judicial decisionmaking bodies that provide a dense web of checks and balances (Strauss, 1984; Eskridge and Ferejohn, 1992). Taken as a whole, this system provides a reasonably strong connection between the American public and their political leadership and delivers generally good results over time (Ackerman, 2000).

Historically, the trade regime has not been managed by elected officials accountable to a defined public. Instead, its legitimacy derived almost entirely from its perceived efficacy and value as part of the international economic management structure. ${ }^{3}$ Indeed, the GATT-WTO system may represent the high water mark of the twentieth-century commitment to technocratic decisionmaking (Charnovitz, 1994; Howse, 1999; Shaffer, 1999) and belief in a governance model centered on bureaucratic rationality (Frug, 1984; Weber, 1994). Until recently, the trade regime benefited from a sense that international economics and trade policy making were highly technical realms best left in the hands of an elite cadre of qualified experts. To the extent that links to elected officials were required, the connection between appointed trade officials (both at the national level and in the international domain) and the elected governments to which they reported seemed sufficient.

But public perceptions about trade and trade policy making have changed. Trade is no longer considered to be an obscure policy domain best left to technical experts. Instead, trade issues and initiatives are now a major focus of public attention and discussion across the world. The trade regime can no longer function on the basis of technocratic rationality and quiet accomplishments. As I discuss in more detail below, with its efficacy-based claim to legitimacy under attack and lacking any undergirding in true popular sovereignty, the WTO needs a new foundation for its legitimacy. The organization needs to reestablish its reputation for efficacy and to build new connections to the publics around the world in whose name trade policy is advanced as well as to strengthen the broader institutional structure of checks and balances within which the WTO operates.

2 It will be interesting to see whether this acceptance of 'expert' control over an important realm of policy continues with a faltering economy.

3 When I speak here of the trade 'regime', I mean not only the small Secretariat that works within the World Trade Organization in Geneva but the entire set of trade ministry officials in all of the national capitals who contribute to the WTO policymaking process. 
The World Trade Organization's legitimacy crisis 11

\section{The 'Club Model' trade regime}

From its origins in the General Agreement on Tariffs and Trade (GATT), a cornerstone of the Bretton Woods system that undergirded the post-World War II international economic order (Ruggie, 1983), the trade regime was long operated as a tight-knit 'club' (Keohane and Nye, 2001). This Club Model persisted because it was successful. In fact, the World Trade Organization (and the forerunner structure created under GATT auspices) generated an enviable record of accomplishment with regard to trade liberalization and successful settlement of international economic disputes. Through eight successive rounds of multilateral negotiations, the GATT provided a forum for coordinated commitment to significant tariff reductions and the creation of a system of rules to guide international commerce (Jackson, 1996).

For a long period of time, the trade regime's clubbishness, low profile, and obscure workings were seen as a virtue. A clique of committed economists and diplomats and a small Secretariat in Geneva toiled quietly in pursuit of a vision of open markets and deeper economic integration as both a path to prosperity and a bulwark against the chaos and war that plagued the world through the first half of the twentieth century (Gilpin, 1987; Jackson, 1994). The closed and secretive nature of the regime isolated - and insulated - the trade policymaking process from day-today politics, keeping at bay the protectionist interests that are active in many countries (Schott, 1996).

As a matter of theory, asymmetries of interest and commitment to political activity between the beneficiaries of liberalized trade (the broad public which often neither recognizes the benefits of free trade nor is willing to invest much political energy in defending the gains from open markets) and the losers from trade liberalization (special interests who face new competition and are highly motivated to intervene politically to protect their monopoly rents) create a powerful 'public choice' logic for such a structure (Petersmann, 1992). The international trade regime, as Robert Hudec has described it, serves as a mechanism by which governments can tie their hands to the mast and avoid protectionist siren calls (Hudec, 1971). Under the Club Model, governments operating behind closed doors can cut deals to lower tariff barriers and to open markets for the benefit of the general public out of sight of rent seekers, protectionists, and other special interests (Dijck and Faber, 1996; Jackson, 1996).

But the 'insulation' advantages of the Club Model of trade policy making come at a price. Unable to gain any real appreciation for how the trade regime worked, the public sees the WTO as a 'black box' where insiders take advantage of their access to the levers of power. Fears of special interest domination are now prevalent. And these worries are not limited to the public; many developing countries share the concern (Blackhurst, 2001). The belief that the WTO is dominated by multinational corporations and other elite interests cannot be assuaged without a more transparent policymaking process (Goldman, 1994). The Club Model no longer represents 
therefore a viable management structure for the international economic system. The days of major agreements being hammered out in Geneva hotels by a trade cognoscenti operating under the radar of public view are gone forever. Whatever the virtues of keeping special interests off balance and out of the way, the closed-door style of negotiations that lies at the heart of the Club Model is no longer workable. After years on the periphery of the global scene, trade policy now occupies center stage.

Indeed, for all their confusion (and there has been a great deal), the antiglobalization street protestors have one thing right: the WTO matters. The trade regime stands at the center of the emerging structure of global governance. While there have been many rounds of trade negotiations over the past 50 years, the central focus of the process has shifted from tit-for-tat reductions to the identification of rules and procedures to manage economic interdependence.

In important respects, the next round of negotiations will resemble a Global Constitutional Convention. The process of global constitutionalism - defining core principles, establishing international standards, and creating institutions to manage interdependence - is likely to involve decades or even centuries of discussions and refinements. Nevertheless, the WTO mission must be understood as fundamentally an exercise in global-scale regime building with profound effects for every person on the planet. Such an exercise inherently touches on big questions about how to structure the world in which we want to live and the mechanisms by which we will be governed. In this regard, we must find more robust modalities and substantive principles by which to square the economic gains of more efficient markets with other public priorities, such as poverty alleviation, environmental protection, or the promotion of human rights. The importance of the work of the WTO - including the goals defined, agenda pursued, rules of participation advanced, and the values and assumptions that underpin the discussions - cannot be gainsaid and must be undergirded by a strong foundation of legitimacy.

It is with good reason therefore that the whole world is now watching the WTO and asking questions about the organization's purpose, structure, representation, decision processes, and legitimacy (Bodansky, 1999; Stephan, 1999). Progress in opening markets is no longer justification enough for the organization's existence. Moreover, as I noted earlier, doubts are now being raised in many quarters about whether the WTO is delivering on its mission and promise of greater economic efficiency and prosperity. In the past, only the close-knit trade community - united by a common vision of a world of open markets, a commitment to a well-defined set of core principles (for example, non-discrimination), and common traditions of education (particularly a belief in the centrality of economics) - paid attention to the work of the WTO. Today, a broader community that does not share this cultural affinity and understanding stands in judgment on the organization. Different standards of efficacy are being applied. As a result, the WTO's marks are coming in much lower, eroding the organization's legitimacy. Fundamentally, the closed-door 
approach to decisionmaking that was a virtue under the Club Model has now emerged as an obstacle to popular understanding of and support for the WTO.

Simultaneously, the WTO's efficacy-based claim to legitimacy has been undermined by the trade system's ever-broader reach (Dunoff, 1994; Esty, 1998; Keohane and Nye, 2001). The seeds of the WTO's current troubles were planted dialectically in the furrows of its success. Because the international trade regime is perceived to be effective, increasing numbers of people have come to see the WTO as a key decisionmaking body and an important point of policy leverage (Mearsheimer, 1994/5). Environmentalists, for example, have focused on 'greening the GATT' because there are no international environmental bodies or structures of comparable strength available for advancing pollution control and natural resource management initiatives (Esty, 1994). Similarly, the relative vitality of the WTO's dispute resolution procedures has meant that a wide range of conflicts that involve trade (but other policy domains as well) have ended up being settled within the confines of the WTO (Wofford, 2000). A number of these matters - involving, for instance, the protection of dolphins and sea turtles or the implementation of the reformulated gasoline provisions of the United States 1990 Clean Air Act - have forced the WTO to render judgments that go beyond the scope of its core competence. With its small tradeoriented staff, the WTO is not well positioned to make endangered species or air pollution policy decisions. As a result, there has been substantial unhappiness about the impacts of trade regime decisions in other arenas, such as the environment. Every time the WTO makes 'trade and ...' decisions, it is perceived as over-reaching and its claim to legitimacy based on 'reason' gets strained (Dunoff, 1997).

Acceptance of a decisionmaking process based on bureaucratic rationality can only persist to the extent that the public is convinced that the decisions that are made are 'technical' in nature and undergirded by 'science'. The WTO's impact has clearly moved beyond the narrow realm of trade economics; its decisions inescapably involve trade-offs with other policy goals, broadly affect other realms, and clearly require value judgments. ${ }^{4}$ Under such circumstances, the presumption in favor of technocratic rationality cannot be sustained. And the problem is not merely one of perception. Insofar as the trade agenda intersects with other policy domains such as environmental protection, trade logic and principles cannot be counted upon to reconcile appropriately the competing policy pressures. In sum, while in some policy domains, there continues to be a push for more 'science' as a way of reducing disputes and over-politicization, in trade policy making, the tide is flowing the other way. As the public learns more about the choices to be made, demands for open debate and more 'politics' rise.

To the extent that legitimacy based on rationality erodes, the need for legitimacy based on democracy and links to the public whose interests are being affected

4 Courts similarly have their greatest legitimacy when they address issue-specific concerns raised by particularized parties and rule narrowly (on what might be considered a 'negative' basis - that is, you cannot do...). Affirmative rulings that demand sweeping actions (for example, new laws or regulations) create much more stress and raise legitimate questions. 
mounts. But, here again, the former virtues of the Club Model WTO have become serious detriments. In particular, the WTO's 'membership' policy has emerged as a source of strain. The old Club does not seem adequately representative. For example, the exclusion in Seattle of most developing country representatives from the 'green rooms', where an inner circle of key countries did the real negotiating, raised hackles among many delegates (Blackhurst, 2001). Similarly, the WTO's longstanding exclusion of nongovernmental organizations (NGOs) from its decision processes has become a bone of contention. In addition to developing country negotiators and NGOs, a series of government officials, representing other issue areas (for example, Environment Ministers) were pushed to the fringes of the Seattle convocation. Their presence - and distress - at being marginalized provides further testament to the fissures in the old international regime and the strain on the traditional, issue-based hierarchical structures.

The trade regime's evolving mission has added to the legitimacy crisis. The central focus of trade negotiations is no longer tit-for-tat tariff reductions. Trade policy making now centers on creating a rules-based system to manage international economic interdependence. Moreover, as economic integration deepens, the trade agenda inevitably touches more often and more directly on other issue domains and values (Esty, 2001). Thus, the WTO's recent trouble can, in part, be traced to the failure of many participants in the trade community to recognize the shift that has occurred in their goals over the last decade.

Many free traders argue that their ambition does not go beyond advancing a narrow trade-liberalizing agenda. But as the scope of GATT rules and the other elements of the trade regime have expanded-driven by a shift from a shallow integration model toward a much deeper integration program (Rodrik, 1997; Lawrence et al., 1996) - the WTO's reach has extended into intellectual property, environment, competition rules, and health care policy. Some of these interconnections are not only inevitable, they are desirable. For example, a failure to take account within the trade regime of the possibility of transboundary pollution spillovers would render the international economic system open to market failures resulting in diminished allocative efficiency, reduced gains from trade, and lost social welfare, not to mention environmental degradation. Other interactions have exposed the narrowness of the trade agenda. The clash between the trade system's intellectual property rules as applied to AIDS drugs and the need to treat a major public health crisis in Africa provides one such example (Harrelson, 2001).

Deeper economic integration cannot be sustained without a concomitant deepening of political integration (Dua and Esty, 1997). Some commentators recognize this economics-politics connection but believe there exists a degree of 'useful inefficiency' in the trading system that reduces harmonization pressures and permits divergent domestic policy differences to persist (Cooper, 1968), insulating politicians from the pressures of globalization (Garrett, 1998; Keohane and Nye, 2001). Clearly, there are some buffers which allow some elements of national policy autonomy. Borders do matter (Helliwell, 1998). But those who highlight 
the ongoing vitality of national authorities do little to reconcile their vision of a trade policy buffer with the reality of growing 'sensitivity' created by higher trade-to-GDP ratios and the fact of ever-diminishing inefficiency in international trade.

Economic integration and political integration are interactive and iterative. Progress depends on a deepening sense of community. For the public to be comfortable opening its markets to goods from other jurisdictions, they must believe that these other jurisdictions generally share their core values. And shared values define a community. As the scope and depth of common values expands, so does the sense of community, which makes the public more willing to accept further economic integration. As I explain in more detail below, what is lacking at the WTO is any recognition of the need for more politics - more dialogue and debate, and engagement with civil society - as a way of building the political foundation needed to support the economic structure that is being erected.

The 'democratic deficit' of the WTO goes deeper (Stokes and Choate, 2001). We live in a world where state power has been weakened, and powerful new actors have emerged (Talbott, 1997; Ku, 2001). The theory that a small set of trade officials and representatives-even if appointed by legitimately elected national governments - can appropriately 'represent' the diverse global public has come under strain. National governments simply cannot mediate all global-scale politics (Kobrin, 1998). Even duly elected national governments cannot fully represent all of the voices that should be heard in the global-scale policymaking process (Esty, 1998). The diversity of views is simply too great. Moreover, some of the regimes of WTO members are not fully democratic. Even where elections are held, corruption and elite domination may result in less than fully representative leadership. Derivative legitimacy built on the popular sovereignty of unelected Trade Ministries in distant national governments is simply no longer adequate (Harms, 2000).

Individual identity is also more textured and multi-layered than the traditional model of representation reflects, making geographic electoral constituencies an inadequate foundation for robust public decisionmaking. Many people identify with communities of interest defined by an issue focus (for example, animal lovers, human rights activists, trade union members) as much as they do with geographically defined communities (Esty, 1996). Thus, to limit their participation in global politics to electing national representatives who will designate trade ministry officials to represent the nation in a narrowly confined intergovernmental dialogue produces a terribly thin reed of popular sovereignty on which to build the legitimacy of the WTO.

The distinction here is between representation and representativeness. While it is useful to legitimacy to have the public perceive that it chose (by voting) the decisionmaker, a more powerful sense of comfort with the decision process is generated when individuals feel that not only their votes but their views were taken seriously in the course of policy making. Thus, the process by which public decisions are made always matters (Fiss, 1993). And given the constitutional implications of 
the current WTO agenda, procedural fairness and an open dialogue are of even greater importance (Fiss, 2001).

The idea of global-scale participatory democracy is often dismissed as a utopian dream (Keohane and Nye, 2001). Clearly, with six billion people on the planet, international trade policy decisions cannot be made in a 'town meeting' format. But the WTO policymaking process can be enriched by a shift toward more transparency and open debate that engages non-governmental interests and the spectrum of views from civil society more fully (Habermas, 2001). This does not mean that NGOs will - or should - get to vote when the time comes to make a decision. But it is useful to have the governmental decisionmakers exposed to a range of views, questions, data, analyses, and options. Not only does such a full-scale dialogue provide a forum for intellectual 'competition' that strengthens the ultimate outcome (Esty and Geradin, 2001), the legitimacy of the choice will be enhanced to the extent that the process is perceived as more representative (Esty, 1998).

Modern norms of good public decisionmaking furthermore demand transparency (Florini, 2001; Hansen, 1999). Public acceptance of governmental authority depends on having a clear view of who is making the decision and on what basis they are deciding. This entails administrative law and procedures that reveal the informational foundation for the decision (a public docket) and who has tried to shape the outcome (disclosure of lobbying) (Aman, 2001; Shapiro, 2001). The WTO has some distance to go in adopting such norms of modern policy making.

\section{An alternative model of legitimacy}

Some commentators trace the legitimacy crisis at the WTO to a lack of political accountability. Keohane and Nye (2001, p. 280) for example, conclude that 'politicians are needed who can link specific organizations and policies with a broader range of public issues through electoral accountability'. I see a more granular world. Legitimacy is not simply a function of popular sovereignty and decisionmaking by majority vote. Institutions also win legitimacy and authority because of their capacity to deliver good results and from their systemic ties to other institutions (checks and balances) which provide an indirect link to those who have legitimacy derived through democratic elections. The WTO needs to move forward on all of these fronts.

\subsection{Popular sovereignty}

While global elections and thus directly accountable WTO 'politicians' seem a long way off, the trade regime could dramatically improve the quality, authoritativeness, and representativeness of its decisionmaking and, in doing so, enhance its legitimacy. Lacking any global 'demos', there will inescapably be limits to the accountability of WTO decisionmakers, but improved connections to the national (and sub-national) publics across the world can be established. In particular, non-governmental 
organizations (NGOs) can provide a degree of 'connective tissue', linking distant citizens with the WTO (Esty, 1998). ${ }^{5}$ NGOs can pass information 'down' from the WTO to their constituencies, ensuring better public understanding of the workings of the trade regime. A commitment to transparency and to greater involvement of civil society groups within the WTO would provide trade policymakers with access to fresh thinking, more diverse information sources, and a wide range of viewpoints coming 'up' to Geneva from across the world. The presence of NGO-provided intellectual 'competition' would produce a more vigorous WTO policy dynamic and add to the trade regime's capacity to reflect popular will and to generate wellreasoned outcomes.

To improve its accountability and connection to those with electoral legitimacy, the WTO might also engage more directly with national-scale politicians. One idea would be for legislators from a diverse set of countries to hold joint 'oversight hearings' on the WTO's performance. While the WTO cannot gain the full credibility that might be generated by having directly elected leaders, more outreach and more vigorous policy debates would go some distance towards enhanced legitimacy.

\subsection{Reason}

Trade policy making in its current form is not a technocratic science but rather a broad-gauged realm in which values inevitably play a role and through which the balancing of trade goals with other policy aims must be worked out. The Seattle fiasco marks the death knell of the WTO as a technocratic decisionmaking body operating out of sight. But the trade regime can reclaim a degree of legitimacy based on the rationality of its outputs if its capacity for generating 'right' answers is restored.

As a critical first step, the WTO must trim its sails and reserve its strength for core trade liberalization activities. By retreating from its current role as dispute resolution mechanism to the world, perhaps the WTO can reestablish its reputation for authoritativeness, efficiency, and fairness. Whenever possible, the WTO should avoid making decisions that are viewed as extending beyond its scope of trade competence. The WTO's authoritativeness and legitimacy would be enhanced to the extent that 'trade and environment' problems, for example, could be redirected to a functioning Global Environmental Organization (GEO). ${ }^{6}$ Where decisions inescapably touch other policy domains, more effort should be made to draw in relevant expertise. A more virtual WTO that places itself within a web of global

5 Some critics of a more open WTO fear that a greater NGO presence within the WTO would expose the organization to greater special interest pressures and exacerbate the North-South imbalance because of the likely preponderance of Northern NGOs (Nichols, 1996; Spiro, 1996; Bhagwati and Srinivasan, 1996). But, in fact, the logic runs the other way. Northern NGOs spend most of their time criticizing Northern governments, thereby ameliorating existing imbalances.

6 Of course, today we lack a functioning international environmental regime. For information on ongoing research into the possible structure of a GEO, see the Yale University Global Environmental Governance Web site (http://www.yale.edu/envirocenter/research). 
public policy networks would be more effective and durable (Reinecke, 1997; Slaughter, 1999).

Authoritativeness is also established by the breadth and depth of the debate that takes place when difficult decisions must be made. Especially where there are high degrees of uncertainty over issues, it is important to triangulate on the truth. To ensure the requisite spectrum of viewpoints, the WTO needs a more robust, transparent and participatory decisionmaking processes (Weinstein and Charnovitz, 2001). To the extent that the WTO makes decisions that reinforce a narrow set of values (for example, economic efficiency) and ignore other critical values (environmental protection, human rights, etc.), its credibility and authority suffer damage. The trade community today needs to bend over backwards to recognize the validity of the other policy goals and values that are impinged upon by the trading system.

The WTO's claim to reason-based legitimacy also depends on its perceived fairness and commitment to justice. Fairness has both procedural and substantive elements. A fundamental tenet of procedural fairness or 'due process' is openness - identification of who is making decisions; disclosure of the assumptions on which the process turns; and an explanation of the values, influences, and information sources that are being brought to bear. Procedural fairness also requires appropriate opportunities for interested parties to contribute to the decision process as well as guarantees (enforced through a system of administrative law) that special interests will not be able to manipulate outcomes (Joerges and Dehousse, 2002; Fiss, 1993).

Substantive fairness is a function of consistency across circumstances and time as well as the generation of outcomes that comport community's values and traditions (Fiss, 2001). For the WTO there is a need to ensure that, in addition to getting the right answer from the trade perspective, the institution is capable of cross-issue balancing where other values (for example, environmental concerns) are at play.

\subsection{Systemic reinforcement}

WTO decisionmaking would also be strengthened to the extent it were embedded in a broader structure of 'checks and balances'. 7 As noted above, institutions draw strength from the broader systems of which they are a part. Multiple institutions occupying the same governance 'space' can cross-check and reinforce each other. They can compete and cooperate in pursuit of optimal public decisionmaking (Esty, 1998).

Such an architecture would entail a multi-tier system of international governance that provides a degree of 'vertical' competition between international and national decisionmakers (Esty, 1999; Esty and Geradin, 2001). Simultaneously, the WTO would benefit from greater 'horizontal' reinforcement from other international bodies that have policymaking authority and legitimacy. The presence of a Global

7 The literature on the benefits of checks and balances runs deep (see, for example, Amar, 1987; Strauss, 1984; Webster and Bell, 1997; Ackerman, 2000). 
Environment Organization would, for example, serve as a useful counterweight and counterbalance to the World Trade Organization. Similarly, a revitalized International Labor Organization (ILO) would help to broaden the institutional base of international economic management (Charnovitz, 2000).

\section{Conclusion}

The WTO is capable of regaining broad public acceptance and legitimacy. But a restructuring of the trade regime's substantive rules and procedures will be required.

Effective global institutions whose decisionmaking processes are understood and accepted are essential in a world of complex interdependence. While there may not be a coherent political community at the global scale nor any immediate prospect of accountability in international organizations provided by direct electoral processes, it is possible to envision more representative international decisionmaking bodies, including a revitalized World Trade Organization. Broadening the base of global governance and creating a system of checks and balances that spreads authority horizontally across international organizations as well as vertically across the global and national (and local) scales promises to deliver better results over time. Beyond strengthening its legitimacy through a commitment to more transparent procedures and to providing a forum for broader global-scale political dialogue, the WTO needs to rebuild its reputation for efficacy. To do this, the trade community must show that it recognizes the broader context of the choices made at the WTO and build sensitivity to the stresses of poverty, environmental concerns, human rights issues, and other matters into the trading system. Good governance almost always involves optimization across multiple criteria - and the WTO needs rules and procedures that better balances the (sometimes) competing goals of economic integration, trade, and investment liberalization, and economic efficiency on the one hand, with environmental protection, human rights, equity, and other virtues on the other.

Wistfulness about the disappearance of the Club Model trade regime, the old post-war economic order, and its implied shallow integration should be put aside. Such a vision is both dated and undesirable. Instead, the WTO must be seen as a crucial element of the emerging international governance system. We should acknowledge the challenge - whether we call it global constitutionalism or not - of defining the core principles, rules, and procedures for managing interdependence. Getting the structure of this new international regime right is an important challenge. As a number of commentators on globalization have observed, it is essential that 'space' be reserved for separate domestic political processes (Keohane and Nye, 2001), just as the US Constitution reserves important elements of authority to the states. The trading regime must not over-reach and should maintain the 'escape clauses' and other safety valves (Hudec, 2001) which protect against too much domestic political pressure building up. But it would be a mistake to think that the future of the international economic regime would be on solid footings if we 
ignore the cry for reform or try to shift the focus of the trade debate to domestic fora. Revitalizing the WTO - and reestablishing its legitimacy - must be a high priority.

\section{References}

Ackerman, B. (2000), 'The New Separation of Powers', Harvard Law Review, 113: 633.

Aman, A. C. (2001), 'Globalization, Accountability, and the Future of Administrative Law: The Limits of Globalization and the Future of Administrative Law : From Government to Governance', Indiana Journal of Global Legal Studies, 8 (Spring): 379, 383-384, 396-401.

Amar, A. R. (1987), 'Of Sovereignty and Federalism', Yale Law Journal, 96: 1492 -1519.

Anderson, K. and R. Blackhurst (1992), The Greening of World Trade Issues, Ann Arbor, MI: University of Michigan Press.

Bhagwati, J. (1993), 'The Case for Free Trade', Scientific American, 269 (November): 42.

Bhagwati, J. and T. N. Srinivasan (1996), 'Trade and Environment', in J. Bhagwati and R. E. (eds.), Fair Trade and Harmonization: Prerequisites for Free Trade, Cambridge, MA: MIT Press.

Blackhurst, R. (2001), 'Reforming WTO Decisionmaking: Lessons from Singapore and Seattle', in K. G. Deutsch and B. Speyer (eds.), The World Trade Organization Millennium Round: Freer Trade in the Twenty-First Century, London: Routledge.

Bodansky, D. (1999), 'The Legitimacy of International Governance: A Coming Challenge for International Environmental Law', American Journal of International Law, 93 (July) : 596.

Breton, A. (1996), Competitive Governments: An Economic Theory of Politics and Public Finance, Cambridge: Cambridge University Press.

Charnovitz, S. (1994), 'The World Trade Organization and Social Issues', Journal of World Trade, 28 (October): 17.

- (2000), The International Labour Organisation in Its Second Century', in J. A. Frowein and R. Wolfrum, Max Planck Yearbook of United Nations Law-Volume IV, The Hague: Kluwer Law International.

Cooper, R. M. (1968), The Economics of Interdependence: Economic Policy in the Atlantic Community, New York: McGraw-Hill.

Dua, A. and D. C. Esty (1997), Sustaining the Asia Pacific Miracle, Washington DC: Institute for International Economics, pp. 109-10, 120-127.

Dunoff, J. L. (1994), 'Institutional Misfits: The GATT, the ICJ, and Trade-Environment Disputes', Michigan Journal of International Law, $15: 1043$.

_ (1997), “"Trade And": Recent Developments in Trade Policy and Scholarship - And Their Surprising Political Implications', Northwestern Journal of International Law and Business, 17 (Winter-Spring): 759.

Eskridge, Jr., William N. and John Ferejohn (1992), 'The Article I, Section 7 Game', Georgetown Law Journal, 80: 523-64.

Esty, D. C. (1994), Greening the GATT: Trade, Environment, and the Future, Washington DC: Institute for International Economics.

_ (1996), 'Revitalizing Environmental Federalism', Michigan Law Review, 95 : 570.

- (1998), 'Nongovernmental Organizations at the World Trade Organization: Cooperation, Competition, or Exclusion', Journal of International Economic Law, 1: 123.

- (1999), 'Toward Optimal Environmental Governance', New York University Law Review, 74 : 1495.

- (2000), 'An Environmental Perspective on Seattle', Journal of International Economic Law, 3 : 176.

- (2001), 'Bridging the Trade-Environment Divide', Journal of Economic Perspectives, 15 : 113.

Esty, D. C. and Damien G. (2001), 'Regulatory Co-opetition', in D. C. Esty and D. Geradin (eds.), Regulatory Competition and Economic Integration: Comparative Perspectives, Oxford: Oxford University Press.

Fiss, O. M. (2001), 'The Autonomy of Law', Yale Journal of International Law, 26 (Summer): 517, 520, $525-526$.

_ (1993), 'The Allure of Individualism', Iowa Law Review, 78: 970-971, 978-979.

Florini, A. (2001), 'Decent Exposure', World Link (July/August): 12-13. 
The World Trade Organization's legitimacy crisis 21

Franck, T. M. (1990), The Power of Legitimacy Among Nations, New York: Oxford University Press.

Frug, G. E. (1984), 'The Ideology of Bureaucracy in American Law', Harvard Law Review, 97: 1276.

Garrett, G. (1998), Partisan Politics in the Global Economy, Cambridge: Cambridge University Press.

Goldman, P. (1994), 'The Democratization of the Development of the United States Trade Policy', Cornell International Law Journal, 27: 631.

Gilpin, R. (1987), The Political Economy of International Relations, Princeton, NJ: Princeton University Press. Habermas, J. (2001), The Postnational Constellation, Cambridge, MA: MIT Press.

Hansen, P. I. (1999), 'Transparency, Standards of Review and the Use of Trade Measures to Protect the Global Environment', Virginia Journal of International Law, 39 (Summer) : 1017, 1021, 1061-1068.

Harms, B. C. (2000), 'Holding Public Officials Accountable in the International Realm: A New Multi-Layered Strategy to Combat Corruption', Cornell International Law Journal, 33: 159, 180-181.

Harrelson, J. A. (2001), 'IV. Note: Trips, Pharmaceutical Patents and the HIV/AIDS Crisis: Finding the Proper BalanceBetween Intellectual Property Rights and Compassion', Widener Law Symposium Journal, 7 (Spring): 175.

Helliwell, J. (1998), How Much Do National Borders Matter? Washington DC: Brookings Institution Press.

Howse, R. (1999), 'The House That Jackson Built: Restructuring the GATT System', Michigan Law Review, 20: 107.

Hudec, R. E. (1971), 'GATT or GABB? The Future Design of the General Agreement on Tariffs and Trade', Yale Law Journal, 80: 1299.

- (2001), 'Covenent', in Roger Porter et al. (eds.), Efficiency, Equity and Legitimacy: The Multilateral Trading System at the Millennium, Washington DC: Brookings Institution Press, pp. 295-300.

Hurd, I. (1999), 'Legitimacy and Authority in International Politics', International Organizations, 53 (Spring): 379.

Jackson J. (1994), World Trade and the Law of GATT. New York: Babbs-Merrill.

- (1996), 'Reflections on Constitutional Challenges to the Global Trading System', Chicago Kent Law Review, 72: 511, 519-521.

Jeffress, L. and J.-P. Mayanobe (2001), 'A World Struggle is Underway: An Interview with Jose Bove', Z Magazine, June.

Joerges, C. and Renaud D. (eds.) (2002), 'Good Governance in an Integrated Market', The Collected Courses of the Academy of European Law, Vol. XI, Book 2.

Kahn, P. (1989), 'Reason and Will in the Origins of American Constitutionalism', Yale Law Journal, 98: 449.

Keohane, R. O. and J. S. Nye, Jr. (2001), 'The Club Model of Multilateral Cooperation and Problems of Democratic Legitimacy', in Roger Porter et al. (eds.), Efficiency, Equity and Legitimacy: The Multilateral Trading System at the Millennium, Washington DC: Brookings Institution Press.

Kobrin, S. (1998), 'Back to the Future: Neomedievalism and the Postmodern Digital World Economy', Journal of International Affairs, 51: 362-386.

Ku, C. (2001), 'Global Governance and the Changing Face of International Law', ACUNS Reports and Papers, 2: $1-44$.

Lawrence, R. et al. (1996), A Vision of the World Economy: Openness, Diversity, and Cohesion. Washington DC: Brookings Institution Press.

Mearsheimer, J. (1994/5), 'The False Promise of International Institutions', International Security, 19 (Winter) : 3 .

Nichols, P. M. (1996), 'Realism, Liberalism, Values, and the World Trade Organization', Pennsylvania Journal of International Economic Law, 17: 851, 856-60.

O’Rourke, K. H. (2001), 'Globalization and Inequality: Historical Trends', National Bureau of Economic Research, Working Paper 8339.

Petersmann, E.-U. (1992), 'National Constitutions, Foreign Trade Policy, and European Community Law', European Journal of International Law, $3: 15$.

Reinecke, W. (1997), Global Public Policy. Washington DC: Brookings Institution Press.

Rodrik, D. (1997), Has Globalization Gone Too Far? Washington DC: Institute for International Economics.

Ruggie, J. V. (1983), 'International Regimes, Transactions, and Change: Embedded Liberalism in the PostWar Economic Order', in Stephen D. Krasner (ed.), International Regimes, Ithaca: Cornell University Press. 
Shaffer, G. C. (2001), 'The World Trade Organization Under Challenge: Democracy and the Law and Politics of the WTO's Treatment of Trade and Environment Matters', Harvard Environmental Law Review, $25: 1$.

Schott, J. J. (ed.) (1996), The World Trading System: Challenges Ahead, Washington DC: Institute for International Economics.

Shapiro, M. (2001), 'Administrative Law Unbounded: Reflections on Government and Governance', Indiana Journal of Global Legal Studies, 8: 369.

Simon, H. A. (1996), The Sciences of the Artificial, 3rd edn, Cambridge, MA: MIT Press.

Slaughter, A.-M. (1999), 'The Long Arm of the Law', Foreign Policy, 114 (Spring): 34.

Spiro, P. J. (1996), "New Global Potentates: Nongovernmental Organizations and the "Unregulated" Marketplace', Cardozo Law Review, 19: 957.

Stephan, P. B. (1999), 'Part IV Relationship of the United States to International Institutions: The New International Law - Legitimacy, Accountability, Authority and Freedom in the New Global Order', University of Colorado Law Review, 70 (Fall): 1555.

Stokes, B. and P. Choate. (2001), Democratizing US Trade Policy, New York: Council on Foreign Relations. Strauss, P. (1984), 'The Place of Agencies in Government: Separation of Powers and the Fourth Branch', Columbia Law Review, 84: 573.

Talbott, S. (1997), 'Globalization and Diplomacy: A Practitioner's Perspective', Foreign Policy, 108 (Fall) : 69. van Dijck, P. and G. F. Faber (1996), Challenges to the New World Trade Organization (Legal Aspects of International Organization, 28), The Hague: Kluwer Law International.

Weber, M. (1994), 'The Profession and Vocation of Politics', in P. Lassman and R. Speirs (eds.), Political Writings, Cambridge: Cambridge University Press.

Weber, S. (2000), 'International Organizations and the Pursuit of Justice in the World Economy', Ethics and International Affairs, 4.

Webster, D. and D. Bell (1997), First Principles of Constitutional Revision, Nova Law Review, 22 : 391.

Weinstein, M. M. and S. Charnovitz (2001), 'The Greening of the WTO', Foreign Affairs, 80: 147.

Wilson, J. Q. (1989), Bureaucracy: What Government Agencies Do and Why They Do It, United States: Basic Books.

Wofford, C. (2000), 'A Greener Future at the WTO: The Refinement of WTO Jurisprudence on Environmental Exceptions to the GATT', Harvard Environmental Law Review, 24: 563. 